\title{
ALGEMAS SOCIAIS E FATALISTAS COMO CARACTERIZAÇÃO FEMININA, EM BOQUITAS PINTADAS, DE MANUEL PUIG
}

\author{
SOCIAL AND FATALISTIC HANDCUFFS AS FEMALE \\ CHARACTERIZATION, IN BOQUITAS PINTADAS, BY MANUEL PUIG
}

\author{
${ }^{1}$ Gabrieli Borges dos Santos
}

\begin{abstract}
RESUMO
O presente artigo pretende, a partir de Boquitas pintadas, de Manuel Puig, romance de intuitos populares e forma folhetinesca, proceder à caracterização da personagem Nenê, analisando se as influências sociais (e o poder, em uma sociedade capitalista) podem gerir o comportamento da personagem feminina, sendo esta advinda de uma classe menos prestigiada. Para realizar o que propomos, primeiramente será feita a revisão teórica, que enfocará considerações acerca de literatura e sociedade, conceitos de dialogismo, monologia, polifonia, e ponderações a respeito da personagem e sua caracterização. A seguir, faremos um apanhado de informações acerca de Boquitas pintadas, destacando aspectos gerais de sua constituição. Posteriormente, passaremos à caracterização da personagem Nenê, exemplificando com trechos da obra que auxiliem nas análises necessárias, para enfatizar se há pressões dos fatores sociais sob sua representação. As considerações a que chegamos são de que a caracterização da personagem se dá como resposta ao meio, sendo observada até certo ponto como fatalista, resignada a uma vida infeliz, demonstrando comportamentos que o meio solicitava e que as relações de poder ligadas a questões tanto capitalistas quanto de prestígio social e estigmatização participaram da construção de Nenê, além de influenciarem no desenvolvimento do romance.
\end{abstract}

Palavras-chave: Caracterização. Personagem. Influências sociais. Vozes.

\begin{abstract}
This article describes Nene, a character from Boquitas Pintadas, a popular novel in the form of a feuilleton by Manuel Puig. The characterization is done by analyzing whether social influences (and power in a capitalist society) can control the behavior of the female character, especially as this character comes from a less prestigious class. To this end, the article reviews important aspects related to literature and society, concepts of dialogism, monology, polyphony as well as considerations about the character and characterization. Next, relevant information about Boquitas Pintadas are presented highlighting general aspects of its constitution. After this, Nene's characterization is done, illustrating with
\end{abstract}

\footnotetext{
* Acadêmica do $4^{\circ}$ ano de Letras, com habilitação em espanhol, na Universidade Estadual do Centro - Oeste, unidade universitária de Irati. E-mail: gabrielibs@yahoo.com.br.
} 
excerpts from the novel to help the analysis to verify if there is pressure from social factors in her representation. The conclusions of the analysis show that the characterization of the character is given as answers to the environment, the character is to some extent fatalist, resigned to a miserable life, demonstrating behaviors expected by the society; it is also observed that the power relations are linked to questions of both capitalism and social prestige and that stigmatization influenced the construction of Nene, in addition to influencing the development of the novel.

Keywords: Characterization. Character. Social influences. Voices.

\section{Considerações iniciais}

A literatura hispano-americana se constitui como o terreno do múltiplo, do encontro dos diversos povos e culturas desde suas raízes. As diversas vozes, formas discursivas, heranças, relações com a história, o mito, a política e o entorno social se fazem presentes já na obra que abre a literatura acerca da América, o Diario de cólon (PIERINI, 1994).

Nesse sentido, a literatura hispano-americana tem como tema constante a busca da identidade, tanto das pessoas que são resultado da mestiçagem, como da própria literatura. Assim, aponta-nos Nitrini

[...] é preciso dizer que questões relativas à identidade cultural e a construção de uma literatura nacional ocupam a mente e a pena de escritores, intelectuais, críticos e historiadores há mais de cem anos. (2010, p.63),

fato que marca os textos especializados e literários, vislumbrando-se a consciência da necessidade de uma literatura hispano-americana e não mera de uma continuação do legado deixado pela colonização e depois pela aproximação francesa nas tentativas de neocolonização.

Nesse contexto, os autores impregnam suas produções das preocupações supracitadas, objetivando, a partir do espírito nacionalista, participar da constituição das literaturas nacionais e compartilhar manifestações que constroem a literatura do grande continente americano. Se a língua unifica (não todo o continente, pois ao lado do espanhol, o português, o francês e o inglês se manifestam), as influências, sejam culturais ou literárias, são fecundas e geram dificuldades, até mesmo na delimitação do que é literatura hispano-americana. A herança europeia (principalmente francesa), negra, indígena e norte-americana convivem nos entornos do texto, que é o produto desse encontro, assim como seu contexto social que originou as mais diversas raças que convivem na América Hispânica.

No ponto de vista da crítica, da visão que a europeização impôs (tanto aos próprios hispano-americanos quanto aos europeus), os estereótipos frequentes que ilustram a literatura produzida na América Hispânica vão desde realismo-mágico ou o real maravilhoso, o fantástico, até o eterno barroco (CHIAMPI, 1980). Essas denominações, por vezes generalizadas ou empregadas na falta de melhores, acabam por engessar a literatura hispano-americana, tratando-a apenas como reprodução desse moldes ou, o que talvez seja pior, vendo-a como mera retratação da natureza, da política, como se seu cerne se resumisse a isso.

Agregado à identidade literária, ainda no campo da crítica, não há como deixar de citar o fato de que, muitas vezes, ela começa pelos próprios autores de literatura (como Borges, Cortázar, Fuentes); e a crítica especializada, em parte, incorpora as considerações feitas pelos autores em suas análises, logo, o autor que escreve a literatura é o mesmo que pratica a crítica e elabora sistematizações até mesmo teóricas (CHIAMPI, 1980).

As questões que envolvem a identidade literária, o intento de construir uma literatura nacional que refletisse a sociedade e o povo que ali viviam, também estiveram (estão) intrinsecamente ligadas à temática das obras da América Hispânica. E, como a partir da década de 1960 as revoltas, a política, a organização social, as reivindicações das minorias e o movimento feminista se tornaram recorrências, 
consolidando-se e marcando a história e a sociedade, a literatura como partícipe de tais instâncias também acabou por refletir esse quadro.

$\mathrm{Na}$ obra Boquitas pintadas, do argentino Manuel Puig, percebemos que a caracterização da personagem feminina ocorre, ainda que a priori, em função da sociedade em que está inserida e como reflexo dela. Com isso, pretendemos, tendo em vista a caracterização da personagem Nenê, analisar se as influências sociais (e até certo ponto o poder, em uma sociedade capitalista) podem gerir o comportamento dessa personagem.

As obras de Manuel Puig, mesmo possuindo boa recepção pelo público e por parte da crítica (como a francesa, por exemplo), ainda apresentam, no Brasil, certa limitação, situação que precisa ser revista, ao passo que suas produções vão além das temáticas polêmicas e que geram preconceito. Ainda que as produções literárias do autor se voltem ao apelo popular e quiçá não estejam no círculo das obras consideradas como literatura consagrada, elas são, sem dúvida, passíveis de estudos, não apenas por apresentarem boa recepção, como também por demonstrarem qualidades estético-literárias que merecem ser melhor aclaradas.

Para realizar o que propomos no presente artigo, primeiramente realizaremos a revisão teórica, que enfocará considerações a respeito de literatura e sociedade, conceitos de dialogismo, monologia, polifonia, e ponderações a respeito da personagem e sua caracterização. A seguir, faremos um apanhado de informações acerca do romance Boquitas pintadas, destacando o espaço, o tempo, os meios de construção narrativa, dados de algumas personagens e um resumo do romance. Posteriormente, passaremos à caracterização da personagem Nenê, com o sustentáculo de excertos da obra que auxiliem nas análises necessárias, para enfatizar se há (ou não) pressões dos fatores sociais sob sua representação. A fim de concretizar o que pretendemos, respaldar-nos-emos sobretudo em Brait (1990), Silva (2003), Candido (1970) e Candido (1976).

\section{Pressupostos teóricos}

A relação entre literatura e sociedade já se faz presente desde muito tempo. Segundo o que afirma Antonio Candido, esse relacionamento ocorre de forma recíproca, e isso se refletiu e reflete nos estudos da história da literatura e da crítica literária. Como resultado desse fato, as obras literárias já foram avaliadas e interpretadas tendo em vista o nível em que reproduziam a realidade, a história. Em contrapartida dessa visão, correntes críticas como o Formalismo Russo, e as correntes estruturalistas em geral, "deram autonomia" à obra, encerrando-a nela mesma, interpretando-a nos limites do texto em si, sem considerar qualquer outro elemento, analisando tão somente as estruturas, livrando o texto literário de qualquer amarra com o meio em que foi produzido.

$\mathrm{Na}$ linha de discussão que permeia Literatura e Sociedade e os vínculos de uma com a outra, Antonio Candido (1976), diferentemente das correntes estruturalistas, e também daquelas que veem a obra apenas como reflexo do meio, considera o fator social (um social não tão fechado, incluindo outras possibilidades, como as influências religiosas, políticas, linguísticas, psicológicas) como intrínseco à obra literária e, portanto, não externo, como um mero fator acessório que pode ou não estar presente na tessitura do texto. Com isso, a obra torna-se não apenas espelho do meio; uma vez que o fator social é parte do texto literário e não uma opção do seu autor, ele é condição do texto, portanto, indissolúvel, e, ao se consolidar no texto literário, não o deixa totalmente autônomo em relação ao meio, mas cria uma articulação entre a obra e entorno social:

[...] só a podemos entender [a obra] fundindo texto e contexto numa interpretação dialeticamente íntegra, em que tanto o velho ponto de vista que explicava pelos fatores externos, quanto o outro, norteado pela convicção de que a estrutura é virtualmente independente, se combinam como momentos necessários do processo interpretativo. Sabemos, ainda, que o externo (no caso, o social) importa, não como causa, nem como significado, mas como elemento que desempenha um certo papel na constituição da estrutura, tornando-se portanto, interno. (CANDIDO, 1976, p.4).

Na obra Boquitas pintadas, de Manuel Puig, a ligação entre o literário e a sociedade ocorre de forma que as personagens e as vozes a elas vinculadas, bem como o espaço, sejam influenciados pelo meio, sem deixar de ser literatura. As personagens dentro desse romance são seres sociais; o espaço é reconhecível na realidade empírica mesmo sendo forjado, 
logo, estudar o texto por ele mesmo, seria perder a crítica social que a obra apresenta; e analisar o texto apenas como reflexo do meio seria considerá-lo como apenas mimesis, na interpretação que se deu no Renascimento, uma imitação da realidade.

A personagem, dentro da obra, é uma das instâncias na qual a sociedade é representada, "a influência da sociedade na obra aparece tanto na superfície do texto [...] como na caracterização das personagens (sua psicologia seus preconceitos, ambições etc.) e na estrutura profunda do texto [...]" (SILVA, 2003, p.130); com isso, analisar as relações sociais na literatura vai muito além da superficialidade, em que apenas caracteres ambientas ou físicos se colocam como padrões.

A personagem, sendo uma construção da linguagem, não deixa de ser dialógica. Bakhtin cria a noção de dialogismo, e afirma que a linguagem é necessariamente dialógica, além de prever sempre a imagem de um outro no discurso a quem se tenta persuadir, convencer, com o qual se pretende dialogar; e sendo a literatura uma construção que se dá partindo da linguagem, o dialogismo é também uma de suas características. Com relação ao dialogismo (que ocorre não só entre as personagens, mas também conosco em contato com o livro), uma das formas de ele se expressar é por meio da voz vinculada à personagem. Para Silva, "essa voz não é apenas ligada à expressão das ideias e valores daquele indivíduo; ela expressa valores e ideias necessariamente ligadas a uma instituição social" (2003, p.127). Essa voz social acaba sendo o elo entre a literatura e a sociedade, embora não possamos nos esquecer de que as produções literárias são fictícias e, logo, construídas tendo em vista a verossimilhança e não a realidade externa à obra.

Outro conceito importante de Bakhtin, ainda ligado às vozes, é o de polifonia, juntamente com o de monologia. Na monologia (homofonia), as vozes estão no sentido de que "as personagens e acontecimentos reforçam o ponto de vista do narrador" (SILVA, 2003, p.127), ao passo que na voz polifônica há a "possibilidade de que elas discordem totalmente dos valores, visão de mundo e ideologia do narrador" (SILVA, 2003, p.128). Há, portanto, vários "pensares" distintos que se inscrevem na obra, e que, muitas vezes, também vão dialogar entre si.
Nesse sentido, Bakhtin (2002), ao abordar a obra de Dostoiévski, que seria o criador do romance polifônico, afirma que:

A multiplicidade de vozes e consciências independentes e imisciveis e a autêntica polifonia de vozes plenivalentes* constituem, de fato, peculiaridade fundamental dos romances de Dostoiévski. Não é a multiplicidade de caracteres e destinos que, em um mundo objetivo uno, à luz da consciência una do autor, se desenvolve nos seus romances; é precisamente a multiplicidade consciências equi-

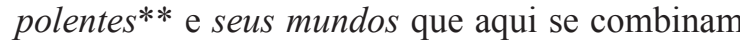
numa unidade de acontecimentos, mantendo a sua imiscibilidade. (p.4).

Antonio Candido (1970), em seu ensaio $A$ personagem do romance, discriminou vários apontamentos acerca da personagem, sua caracterização e origem a partir do real ou como criação. Iniciando suas considerações à personagem, o autor pontua, como uma das características mais marcantes, que a personagem é fragmentária; porém, na obra temos a impressão de estar diante de um todo, e não de partes que constituem a personagem. Nesse sentido, Candido nos aponta que "essas considerações visam mostrar que o romance, ao abordar as personagens de modo fragmentário, nada mais faz do que retomar, ao plano da técnica da caracterização, a maneira fragmentária, insatisfatória, incompleta do conhecimento dos nossos semelhantes" (1970, p.58). E completa: "no romance, ela [a visão fragmentária] é criada, é estabelecida racionalmente dirigida pelo escritor, que delimita e encerra, a numa estrutura elaborada, a aventura sem fim que é, na vida, o conhecimento do outro" (CANDIDO, id.).

Mesmo que a personagem tenha a condição de fragmentária, e que possamos imputar-lhe múltiplos olhares, para Candido, "no romance, podemos variar relativamente a nossa interpretação da personagem; mas o escritor lhe deu, desde logo, uma linha de coerência fixada para sempre, delimitando a curva de sua existência e a natureza de seu modo de ser" (1970, p.59). Então, ainda que possamos esboçar, por meio da subjetividade, características diferentes para a personagem, se não houver, dentro do que o autor fixou na coerência, brechas que deem essa possibilidade, ela não se confirmará.

Ainda tomando a problemática com relação à construção da personagem, segundo Candido 
a personagem é complexa e múltipla porque o romancista pode combinar com perícia os elementos de caracterização, cujo número é sempre limitado se o compararmos com o máximo de traços humanos que pululam a cada instante o modo-de-ser das pessoas" (1970, p.59-60). Com isso, embora o autor possa combinar os elementos de construção da personagem, como já exposto, eles são limitados, fazendo com que a caracterização venha a "depender de uma escolha e distribuição conveniente de traços limitados e expressivos, que se entrosem na composição geral e sugiram a totalidade dum modo-de-ser, duma existência. (1990, p.75).

Logo, a personagem é, ao mesmo tempo, produto da linguagem e, ainda que inconscientemente, produto das escolhas e focalizações feitas pelo autor enquanto criador.

Delineando traços definidores das personagens, tais como costume e natureza, vislumbramos dois grupos, conforme suas peculiaridades:

na técnica da caracterização definiram-se, desde $\log$, duas famílias de personagens, que já no século XVIII Johnson chamava 'personagens de costume' e os 'personagens de natureza' [...] As 'personagens de costume' são, portanto, apresentados por traços distintivos, fortemente escolhidos e marcados; por meio, em suma, de tudo aquilo que distingue vistos de fora. Êstes traços são fixados de uma vez para sempre [...] As 'personagens de natureza' são apresentadas, além dos traços superficiais, pelo seu modo íntimo de ser, e isto impede que tenham a regularidade dos outros. (CANDIDO, 1970, p.61-2).

Com relação aos não acordados meios em que se oriunda a personagem, Antonio Candido vem traçando vários deles, sobrepondo a ficção, ou o ato criador, como primordial:

em tais casos, as personagens obedecem a uma certa concepção de homem, a um intuito simbólico, a um impulso indefinível, ou quaisquer outros estímulos de base, que o autor corporifica, de maneira a supormos uma espécie de arquétipos que, embora nutridos da experiência de vida e da observação é mais interior que exterior. (1970, p.73).

A personagem é caracterizada por vários caracteres, físicos, psicológicos, comportamentais, e conforme sua evolução na obra. Passando a pensar essas caracterizações e classificações que as per- sonagens sofreram e sofrem, citaremos algumas, iniciando por Forster (1927). Segundo esse autor, as personagens podem ser planas ou redondas: as planas "são construídas ao redor de uma ideia ou qualidade. Geralmente, são definidas em poucas palavras, estão imunes à evolução no transcorrer da narrativa" (apud BRAIT, 1990, p.41); e redondas são "aquelas definidas por sua complexidade, apresentando várias qualidades ou tendências, surpreendendo convincentemente o leitor" (ibidem).

Ainda, além da classificação geral supracitada, de planas ou redondas, as personagens planas podem ser designadas como de tipo e caricatura. Brait afirma que "são classificadas como tipo aquelas personagens que alcançam o auge da peculiaridade sem atingir a deformação" e "quando a ideia ou qualidade única é levada ao extremo, provocando uma distorção propositada, geralmente a serviço da sátira, a personagem passa a ser caricatura" (1990, p.41).

Com a evolução dos estudos literários, Philippe Hamon (1972, apud BRAIT, 1990), embasado na semântica, sintaxe e pragmática, propõe três tipos de personagens: referenciais, embrayeurs e anáforas. A personagem referencial é aquela associada normalmente a uma personagem histórica, e faz alusão a uma direção fixa e plena. A embrayeurs depende das outras personagens para ser compreendida, funciona como um elo. E a anáfora é aquela que, para ser totalmente percebida, necessita estar inserida nas relações que a obra efetua $(i d$.).

Considerando a caracterização da personagem propriamente, subsidiando-nos ainda em Brait (1990), dentro do romance ela pode ser apresentada ao leitor de alguns modos: pelo narrador, fora ou dentro da narrativa ( $1^{\mathrm{a}}$ ou $3^{\mathrm{a}}$ pessoa), que focaliza determinados registros importantes da personagem; por meio de uma outra personagem; por uma personagem secundária; ou a personagem mesma se apresenta a partir de recursos como monólogos, cartas, diários, fluxos psicológicos, memórias. Em algumas obras, a personagem pode ser caracterizada por mais de um desses elementos, caso de Boquitas pintadas.

Detendo-nos um pouco mais na personagem que se apresenta sem a intervenção de outra personagem, como já exposto, os recursos utilizados vão direcionar para "presentificar a personagem, expondo sua interioridade de forma a diminuir a 
distância entre o escrito e o vivido" (BRAIT, 1990, p.61). Com isso, sem a intervenção do narrador, a proximidade do leitor com a personagem é maior, e a relação com os fatos também, pois o impacto/ recepção de um narrador em terceira pessoa é diferente daquele em primeira, sem que um seja melhor ou pior do que o outro.

\section{Boquitas Pintadas: constituição geral}

A obra Boquitas pintadas foi escrita por Manuel Puig, escritor argentino que, por muito tempo, acreditou ter no cinema sua vocação, o que se fez presente em suas obras literárias, seja pela técnica de construção do enredo, pelo gosto que os filmes despertam em suas personagens ou pelas adaptações fílmicas de algumas de suas produções. Todavia, o próprio Puig percebeu que seus escritos propendiam muito mais à literatura do que ao cinema.

O romance Boquitas pintadas (ou Boquinhas pintadas, em português) foi composto a partir da estrutura popular do folhetim, separado em duas partes: a primeira, "Boquitas Pintadas de Rojo Carmesí", com oito fascículos, e a segunda, "Boquitas Azules, Violáceas, Negras", com mais oito fascículos, ao longo de 192 páginas. Como precedente de cada fascículo há dois versos de tango ou bolero.

Com relação ao espaço do romance, ele é amplo e demarcado, figurando Coronel Vallejos, Buenos Aires e Cosquín, província de Córdoba. Quanto ao tempo, é cronológico, contudo não linear, pois cartas, rememorações, descrições vão construindo o passado e se entrelaçando com o presente. O romance apresenta peripécias de várias personagens, sendo a protagonista Juan Carlos. As personagens centrais são Nélida (Nenê), Mabel, Celena, Pancho e Rabadilla, que se entrecruzam de algum modo com Juan Carlos, e suas "vidas" são contadas por meio de diversas técnicas narrativas, constituindo quadros que formam a obra. Há, ainda, personagens secundários, como Cecil, que foi noivo de Mabel; Massa, marido de Nenê; Dona Leonor, mãe de Juan Carlos; os pais de Nenê; algumas mulheres com quem Juan Carlos se envolve; os filhos de Nenê e Mabel e alguns outros que não participam ativamente da narração.

O romance é composto de modo fragmentário e heteroglóssico. A narração do que ocorre com as personagens e a reconstrução do passado acontece por meio de cartas, páginas de agendas, recortes de jornal e fluxos de pensamento. Além de prontuários médicos, relatos objetivos do que aconteceu com cada personagem em determinados momentos, falas com partes em itálico sugerindo que pode ser o que a personagem gostaria de ter dito ou o que ela pensou, maiores medos, desejos, o que sentiu em determinada situação, confissões, orações, diálogos e inscrições na lápide de Juan Carlos.

Em resumo, a obra inicia-se com a representação de um recorte de jornal que relata a morte de Juan Carlos, e com uma carta de Nenê a Dona Leonor, mãe de Juan Carlos, escrita devido à morte do protagonista, pedindo, se possível, as cartas que um dia Juan Carlos havia-lhe escrito. Depois disso, o passado vai sendo construído com as epístolas de Nenê, nas quais se inserem as memórias, as intrigas, os amores, juntamente com o presente dela, em um casamento que a deixa infeliz; com a situação de Rabadilla, enganada por Pancho; com Mabel, que assim como Nenê amou Juan Carlos, depois teve um noivado, que foi interrompido; com Celina amargurada, passando seus dias como professora e tentando manter as aparências - tudo isso tendo como cenário uma Argentina nostálgica, conservadora no que tange às relações sociais, culturais, aos paradigmas de comportamento (principalmente de herança europeia) e, em que o poder determina as pessoas, fatigadas pelas desventuras, desencontros, tristezas, mesmices e máscaras sociais.

A seguir, passaremos a tratar especificamente da personagem Nenê.

\section{Nélida, Nenê, da classe desprestigiada a um casamento infeliz}

A personagem Nélida Fernández Massa se caracteriza, em Boquitas pintadas, tanto por sua própria voz como pela dos outros; em outras palavras, como aponta Brait (1990), a personagem se apresenta por ela mesma, ainda que de forma indireta, e por outros personagens (como Celina, e em certos momentos Pancho). Essa apresentação de Nenê por ela mesma, na maior parte da obra, quebra a distância leitor-personagem que muitas vezes um narrador impõe, lançando-nos diretamente aos fatos e aumentando a intimidade, como se a olhássemos por nós e não pelos olhos do outro. Além disso, a 
construção da personagem ocorre de maneira dialógica e polifônica. Há mais de uma visão de Nenê: a dela mesma, a de Celina, a de Pancho e de outras personagens - essas visões distintas são dadas pelas vozes.

Não temos, no decorrer do romance, uma imagem delimitada de Nenê; o que percebemos são alguns traços, como o cabelo louro com ondulações, estatura mediana, pele branca, sem mais detalhes pontuais. Sua idade também varia: quando conheceu Juan Carlos tinha cerca de 20 anos, durante a escritura das cartas destinadas a Dona Leonor, 29 anos, e em sua morte, 52 anos.

Nas primeiras cartas, em que nos deteremos mais demoradamente, a personagem Nélida Fernández Massa aparece pela primeira vez no romance, por meio de uma epístola a Dona Leonor, mãe de seu ex-noivo. Nela notamos que a personagem se exibe com formalismo quando inicia a carta dizendo "Estimada Dona Leonor" (p.11) e termina com "Nélida Fernández Massa" (p.12), assinalando um distanciamento, ao mesmo tempo em que tenta recompor laços do passado, como em "lembra-se de mim?" (p.12) e põe-se pesarosa e solícita - "me atrevo a lhe enviar os meus mais sentidos pêsames pela morte de seu filho" (p.11), "faço votos que o Nosso Senhor a ajude" (p.12) e "peço-lhe que me permita rezar com a senhora" (p.12).

Na sequência, observamos outra carta de Nélida, como resposta à carta que Dona Leonor, supostamente, havia-lhe enviado e que não consta na obra. Podemos perceber na carta mais algumas características da personagem, como o estado em que se encontra no momento em que a escreveu: "estou tão triste, mas isso é justamente o que eu não devo lhe dizer, e sim consolá-la" (p.13); que tem mais de um filho: "meu filhinho menor esteve doente" (p.13); e seus vínculos religiosos: "agora voltei a rezar" (p.13) e "creio que isso é mal visto pela religião católica, porque o catecismo diz que depois do juízo final virá a ressurreição de corpo e alma [...] vou perguntar a algum padre sobre isso" (p.13). Ademais, o distanciamento de Nélida e Dona Leonor é reduzido quando a carta começa com "Querida Dona Leonor" (p.12) e se encerra "um abraço da Nélida".

Segue-se outra carta de Nélida a Dona Leonor, com maior grau de intimidade, pois começa a relatar sua vida e termina com "Abraça-a e beija-a Nenê" (p.15). Nesse trecho, algumas concepções e condições da vida atual da personagem vão se delineando: "hoje sou uma mulher casada e com filhos sadios, dois meninos, um de oito e outro de seis, que Deus os conserve comigo", e "eu não deveria estar pensando em coisas que aconteceram antes do casamento" (p.14). É uma mulher casada, com dois filhos, e que tem uma visão conservadora do casamento, dizendo não poder pensar no que ocorreu antes dele, principalmente no que tange às relações amorosas, como foi o caso de Juan Carlos.

Com a última carta desse fascículo, algumas outras informações da personagem assomam. Mesmo que Nélida ainda não tenha um rosto, perfil físico traçado, na carta percebemos um indício, mesmo que este seja temporário, de seu aspecto corpóreo, "estou com a fisionomia muito abatida" (p.19). Então prossegue falando da sua condição psicológica, que "a manhã passa para mim mais ou menos distraída, mas a tarde, como é triste Dona Leonor" (p.19) e "hoje uma vizinha veio me devolver o ferro de engomar que lhe emprestei ontem e quase lhe volvo o rosto, sem nenhuma razão" (p.19).

Há ainda um dado referente à idade da personagem, que escreve a carta na data de "Buenos Aires, 14 de julho de 1947" (p.18), e mais adiante, na mesma carta, acrescenta "mando-lhe junto um recorte da revista Nossos vizinhos, a respeito da festa da primavera, creio que em 1936, pois eu tinha acabado de completar os vinte anos" (p.19). Com isso, podemos delimitar que a personagem tem cerca de 29 anos, e, pela representação de um recorte de revista, sabemos que Nélida foi eleita rainha da festa da primavera. Há também alguns dados de como era na idade de 20 anos e que ela estava com Juan Carlos, "eleita Rainha da Primavera 1936 a encantadora Nélida Fernández, cuja esbelta silhueta engalana estas colunas [...] uma valsa vienense de fins do século passado executada com notável ímpeto pela Srta. Nélida Fernández e pelo Sr. Juan Carlos Etchepare" (p.20).

No segundo fascículo, vislumbramos características inerentes à posição social de Nélida e às implicações que por isso sofria, como quando a mãe de Nenê fala a respeito dela que "não queria de forma alguma que eu [Nenê] frequentasse os bailes do Social. Quais as moças que iam ao Social? Moças que 
podiam ir bem vestidas, ou porque os pais tinham boa posição ou porque eram professoras [...] Dizia mamãe que me intrometendo onde não era meu lugar [...]" (p.22-3). Nesse excerto, percebemos que a personagem sofria um certo tipo de diferenciação pela posição social que ocupava, até mesmo pela sua própria mãe, que dizia que um local frequentado por pessoas que advinham de "boa" família ou possuíam formação como professoras não era para ela, além dos comentários impetrados por Celina, que dizia que Nenê só fazia parte do Clube Social por ser sua amiga.

Ainda com relação à posição social, Nenê, em carta a Dona Leonor questionando as ocorrências passadas, indaga: "por que ela [Celina] não se animou a pedir o mesmo a Mabel? Por que Mabel tinha dinheiro e eu não? Ou por que Mabel era professora e eu só tinha ido até o sexto ano?" (p.23) e "Meu pai não teve meio de me fazer estudar, custava muito dinheiro me mandar para o Lincoln para me formar como professora, ele não passava de um jardineiro e com muita honra" (p.29). Por meio dessas compilações notamos que Nenê fazia parte de uma classe menos favorecida em relação a Mabel, que não completou sua formação por seu pai não dispor de meios financeiros, e que por isso Celina acabava por inferiorizá-la.

No que tange aos fatos anteriores à data em que Nenê conhece Juan Carlos, percebemos eventos que vão acompanhá-la por todo o romance e refletir nas suas relações: "quando deixei de repente o consultório, começaram a sussurrar que havia acontecido algo sujo entre mim e o doutor, ele homem casado e com três filhos" (p.25) e "e como me saiu caro por um momento ter ficado maluca!" (id.). Nessas duas falas aparecem dois momentos distintos para a personagem: ela cometer um ato de que se arrepende e os comentários que as pessoas esboçaram, julgando, a partir das impressões de Nenê, que ocorreu algo sujo. Podemos assinalar nesse caso as imputações sociais que relações extraconjugais sofreram e sofrem, nesse caso nem tanto para o homem, mas para Nenê, além de que, ter relações sexuais antes de se casar é um padrão que a sociedade não admitia, algo com que a personagem acaba se preocupando, como quando pensa em contar ou não e quando a Juan Carlos a respeito do que aconteceu entre ela e o Doutor Aschero.
Com as pressuposições de Brait (1990) e Candido (1970), quando retomam os apontamentos feitos por Forster, que classifica as personagens em planas, "construídas ao redor de uma ideia ou qualidade. Geralmente, são definidas em poucas palavras, estão imunes à evolução no transcorrer da narrativa" (BRAIT, 1990, p.41), e, redonda (ou esférica) "aquelas definidas por sua complexidade, apresentando várias qualidades ou tendências, surpreendendo convincentemente o leitor" (ibidem). Tencionamos que Nenê se mantém plana, linear no desenvolver do romance, mas no fim ela se arredonda; quiçá isso seja o que a torna a personagem mais interessante.

Nenê se constrói, na narrativa, como uma personagem apaixonada por Juan Carlos; acreditava que ele iria se casar com ela. Mesmo depois de contrair matrimônio com outro homem ainda nutre um sentimento por ele e afirma: "Nunca gostei dele [seu marido] como gostei de Juan Carlos, realmente o único a quem quis foi Juan Carlos" (p.25). Quando se refere ao marido diz "e agora tenho que aguentar o chato do Massa por toda a vida" (p.25) e complementa, "Veja, vou morrer assim, nesta vida que estou levando, apenas trabalhar em casa e brigar com os meninos" (p.26).

Caracteriza-se também por uma ingenuidade perante Juan Carlos. Em todo o decorrer do romance se fiou que se ela e o ex-noivo romperam foi por causa de Celina, que os quis separar para que Juan Carlos ficasse com Mabel por esta possuir mais dinheiro. Não estava enganada de todo, pois Celina realmente preferia Mabel; quanto a Juan Carlos, mesmo que no final de sua vida ele falasse que Nenê era a única mulher com quem ele chegaria a se casar, no momento em que estavam noivos, "Juan lhe disse que assim que conseguisse o que queria, romperia com Nenê, e pediu a Pancho que jurasse não contar a ninguém" (63-4).

Mesmo com isso, Nenê passou sua vida acreditando que a coisa mais bela que viu na vida foi o rosto de Juan Carlos e que os dois iriam ficar juntos depois da morte. Como vislumbramos, a personagem havia pedido que quando morresse "entre a mortalha e seu peito, fosse colocado o maço de cartas [de Juan Carlos] já referido" (p.188). Até esse instante a personagem continua em seu molde planificado, seguindo o comportamento que dela 
esperamos. Teve na vida sua família, com marido e dois filhos que não a faziam feliz - pelo menos é a impressão que temos pela narração do romance -, queixava-se da vida que levava e dizia coisas do tipo: "felizmente que ainda não tenho móveis de boa qualidade, é por isso que ainda não chamei a gente de Vallejos para que me visitem, depois saem criticando que não tenho a casa devidamente mobiliada, com luxo" (p.26), o que mostra que a preocupação com o que as pessoas achariam dela, de sua casa, e até mesmo do padrão de casamento ideal tipus forma recorrências em sua voz até quase o fim do romance.

A personagem Nenê passa pela narrativa, ou o caminho que ela percorre, e não necessariamente o fim a que chega é marcado pelo fatalismo. Ela se sente inferior a Celina e Mabel por não ter completado seus estudos como elas, por ter menos dinheiro; resigna-se a reclamar do casamento insatisfatório, dos filhos que lhe aborrecem, enfim, de não ter tido oportunidades, sem avaliar as situações de forma mais profunda, ou fazer algo para mudar seu estado.

Ao final do romance, Nenê arredonda-se. De 1947 até 1968 não há registros do que aconteceu com as personagens; o último fascículo começa com o anúncio da morte de Nenê, conferindo assim uma ciclicidade ao romance, uma vez que o início da obra ocorre com o relato da morte de Juan Carlos. Com o desfecho, a linearidade, a previsibilidade de Nenê é rompida. Quando a personagem pede que "no ataúde fosse colocado, na palma de suas mãos, outros objetos [que não as cartas]: uma mecha de cabelo de sua única neta, o reloginho pulseira que ela dera de presente a seu segundo filho quando este fez a primeira comunhão e a aliança de casado de seu esposo" (p.188), a sequência de resignação da qual ela advinha e de fixação em Juan Carlos é desfeita, ela abre mão do que viveu no passado, de todo o sentimento que dispensou ao ex-noivo e pede objetos de seus filhos, neta e do marido, que têm um valor simbólico: ela então dá maior importância a sua atual situação, à família de quem ela tanto reclamava, fazendo com que uma nova ordem impere, e dotando Nenê de valores que ela não apresentou no restante da obra, como o apego à família. Com isso, Nenê assume um papel mais aceitável socialmente, pois entre um amor do passado e a família, para a mulher é praticamente imposição ter a família em primeiro lugar.
Ainda que, como nos mostra Antonio Candido (1970), a personagem seja um ser fragmentário na construção da linguagem, ela é caracterizada por vários traços, desde os físicos, psicológicos, comportamentais e conforme sua evolução na obra. A partir disso, elencaremos os fatores como concepções, preconceitos e padrões sociais, que também são partícipes dessa caracterização, ao passo que fazem parte tanto das questões psicológicas como da personagem. Para percebê-los, partiremos de algumas falas de Nenê.

No excerto "no meu caso, foi um só, e assim mesmo porque eu era menina, ao contrário dela [Celina], que sujaram o nome até cansarem. E ficou solteira, e essa é a sua raiva maior, por ter ficado solteira!" (p.28), percebemos traços característicos de vinculações sociais - as duas personagens viveram fatos parecidos em relacionamentos e Nenê, mesmo sabendo que as pessoas comentaram a seu respeito e ela não gostou, faz o mesmo com Celina, ainda se desculpando com o "comigo foi diferente". Outra característica social que se corporifica com essa citação é a quase obrigatoriedade do casamento à mulher, tanto que a personagem Celina ter ficado solteira, segundo Nenê, lhe causa raiva, e dá a entender, ademais, que mesmo que Nenê no passado tenha tido relacionamentos que a sociedade condena, assim como a própria Celina, ela conseguiu se casar, chegando a se sobrepor a Celina por esse fato.

Com relação à polifonia, às várias vozes ou pontos de vista que flutuam na narrativa, temos, além da voz da própria Nenê, a visão de Nenê imputada por Celina. Para Celina, Nenê foi quem tirou a vida de Juan Carlos; levou-o a agir da forma como se comportava, além de, no passado, ter se envolvido com Doutor Aschero, fato que todos comentam. Celina, em um trecho que relata uma oração sua diz: "Jesus, peço que faças justiça, que essa mulher [Nenê] receba o castigo que merece, um rapaz fraco, resfriado, e ela o obrigava a ficar horas e horas nesse portão, até a madrugada, fazia-o ficar com suas artimanhas!" (p.172). Contudo, nem por isso podemos julgar Celina como má ou antagonista; o que ocorre é um ponto de vista distinto, endossado pelo próprio Juan Carlos que, para omitir o que realmente fazia, dizia que estava com Nenê, como quando questionado do porquê de haver estado até a madrugada fora de casa, observamos: "Sua mãe respondeu que 
ele devia ter estado com Nélida. Juan Carlos confirmou" (p.50).

Outra constante na vida de Nenê são as comparações que fazia de sua vida com a dos outros. Quando Mabel fala a respeito de seu noivo, "Nenê pensou quão mais importante que um leiloeiro público seria um bacharel em Ciências econômicas" (p.150), ela concebia seu marido e filhos pela analogia, pensando que seu marido, por exemplo, possuía menos importância pela sua profissão, que seus filhos para ela eram mais feios do que as outras crianças da rua. Nenê não desvinculava o olhar do outro social, que articula valoração através do status financeiro, de beleza, ou profissional. Para a personagem, a importância de sua casa, dos filhos e do marido não estava no juízo que ela fazia a respeito deles, e sim nas implicações de valor que eles possuíam se comparados aos padrões aceitáveis e prestigiados pela sociedade.

Com relação à polifonia, às várias vozes ou pontos de vista que flutuam na narrativa, temos, além da voz da própria Nenê, a visão de Nenê imputada por Celina. Para Celina, Nenê foi quem tirou a vida de Juan Carlos, levou-o a agir da forma como se comportava, além de, no passado, ter se envolvido com o Doutor Aschero, fato que todos comentam. Celina, em um trecho que relata uma oração sua diz: "Jesus, peço que faças justiça, que essa mulher [Nenê] receba o castigo que merece, um rapaz fraco, resfriado, e ela o obrigava a ficar horas e horas nesse portão, até a madrugada, fazia-o ficar com suas artimanhas!" (p.172). Contudo, nem por isso podemos julgar Celina como má ou antagonista; o que ocorre é um ponto de vista distinto, endossado pelo próprio Juan Carlos que, para omitir o que realmente fazia, dizia que estava com Nenê, como quando foi questionado de por que havia estado até a madrugada fora de casa: "Sua mãe respondeu que ele devia ter estado com Nélida. Juan Carlos confirmou" (p.50).

\section{Considerações finais}

A partir das considerações apresentadas no presente artigo, constatamos que a personagem, mesmo sendo um ser fictício e fragmentário, é composta por diversas partes que a caracterizam. Além do mais, uma mesma personagem pode ser edificada de forma dialógica, por meio de mais de uma voz, de um ponto de vista na obra, ou seja, ela pode ser construída de modo que mais de uma perspectiva ou forma de se ver essa personagem se projete no texto literário. Esse é o caso de Nenê, que é caracterizada pela sua própria voz e pela voz do outro, seja Celina, Pancho ou outra personagem. Como consequência disso, temos "Nenês", caracterizadas dependendo da focalização empregada.

Há, ainda, a personagem construída pela linguagem, corporificando-se pelas vozes que se inscrevem no texto, que são também produtos sociais, pois não estão apenas ligadas às personagens, mas fazem parte de ideias, padrões de comportamento e valores da instituição social (da qual participam elementos como o contexto, questões religiosas, ideológicas, políticas e paradigmas) que permeiam a obra.

A personagem Nenê, pertencente à classe menos prestigiada, casa-se com Massa, busca uma vida melhor nos moldes burgueses, vive de suas lembranças e amores passados, mostra-se de forma por vezes quase ingênua, comparatista, fatalista, resigna-se a passar pela vida cuidando da casa, dos filhos, com um marido que, pelo que se narra, ela não suporta. O que lhe sustenta é a recordação de Juan Carlos e a possibilidade de ficarem juntos no post mortem. Com a proximidade de sua morte, essa ordem se rompe e, ao invés de querer as cartas de Juan Carlos, elenca objetos de sua família para levar com ela, demonstrando que, ainda que tenha cumprido os padrões imputados à mulher pela sociedade, foi feliz e aceitou enfim sua família como fator mais significativo de sua vida.

Não tivemos como pretensão, com as ponderações acerca de Nenê, esgotar os elementos que compõem a personagem, ou as possibilidades de leitura da obra de Puig. O que fizemos foi, partindo de conceitos como dialogismo e polifonia, de Bakhtin, de caracterização de personagem, com os tratados de Candido e Brait, e as considerações que relacionam literatura e sociedade, mostrar que a personagem de ficção também pode possuir vínculos sociais, mas que também é composta por outros elementos, quais sejam os psicológicos, ideológicos, históricos, entre outros, e que estes são passíveis de estudos de igual maneira. 


\section{Referências}

BRAIT, B. A personagem. 4. ed. São Paulo: Ática, 1990.

BAKHTIN, M. Problemas da poética de Dostoiévski. Tradução de Bezerra Paulo. 3 ed. Rio de Janeiro: Forense Universitária, 2002.

CÂNDIDO, A. Literatura e sociedade: estudos de teoria e história literária. 5. ed. rev. São Paulo: Editora Nacional, 1976.

A personagem do romance. In: CÂNDIDO, A.; ROSENFELD, A.; PRADO, D. A.; GOMES, P. A personagem de ficção. São Paulo: Perspectiva, 1970. p. 53-80.

CHIAMPI, I. O realismo maravilhoso. São Paulo: Perspectiva, 1980. p. 08-15.

MACHADO, I. A. O romance e a voz: a prosaica dialógica de M. Bakhtin. Rio de janeiro: Imago Ed., São Paulo: FAFESP, 1995.

NITRINI, S. Literatura comparada: história, teoria e crítica. 3. ed. São Paulo: Editora da Universidade de São Paulo, 2010. p. 63-89.

PIERINI, M. La mirada y el discurso: la literatura de viajes. In: PIZARRO, A. (Org.). América latina: palavra, literatura e cultura: a emancipação do discurso. 2 v. São Paulo: Memorial; Campinas; Ed. da UNICAMP, 1994. p.161-183.

PUIG, M. Boquinhas pintadas. São Paulo: Abril Cultural, 1976.

SILVA, M. C. Crítica sociológica. In: BONNICI, T.; ZOLIN, L. O. (Orgs.). Teoria literária: abordagens históricas e tendências contemporâneas. Maringá: Ed. da UEM, 2003. p.123-133.

Recebido em: 02/01/2012.

Aprovado para publicação em: 24/04/2012 